\title{
Rasio Kemandirian Keuangan Daerah dan Pertumbuhan Ekonomi terhadap Indeks Pembangunan Manusia di Provinsi Banten
}

\author{
Wahyu Mauludin \\ Program Studi Pendidikan Ekonomi, Fakultas Ekonomi, Universitas Negeri Surabaya \\ email : wahyumauludin16080554076@mhs.unesa.ac.id \\ Retno Mustika Dewi \\ Program Studi Pendidikan Ekonomi, Fakultas Ekonomi, Universitas Negeri Surabaya \\ email : retnomustika@unesa.ac.id
}

\begin{abstract}
Abstrak
Latar belakang penelitian ini adalah permasalahan pembangunan manusia di Provinsi Banten dari dimensi pendidikan yaitu masalah kesenjangan dan ketidakmerataan yang disebabkan keterbatasan anggaran pemerintah pada bidang pendidikan. Jenis penelitian ini merupakan penelitian kuantitatif, karena data dan hasil penelitian berbentuk angka. Tujuan penelitian ini adalah (1) menganalisis pengaruh rasio kemandirian keuangan daerah terhadap IPM. (2) menganalisis pengaruh pertumbuhan ekonomi terhadap IPM dan (3) menganalisis pengaruh rasio kemandirian keuangan daerah serta pertumbuhan ekonomi bersama-sama terhadap IPM kabupaten/kota Provinsi Banten periode 2013-2017. Populasi pada penelitian ini berjumlah 40 di 8 kabupaten/kota Provinsi Banten dengan rentang waktu 5 tahun dari tahun 2013 sampai 2017. Sampel penelitian ini merupakan sampel jenuh yang menggunakan seluruh anggota populasi berjumlah 40 data. Teknik analisis data menggunakan regresi data panel diolah dengan aplikasi Eviews 9.0. Hasil dari penelitian ini adalah terdapat pengaruh simultan antara variabel independen dengan variabel dependen. Sedangkan secara parsial, rasio kemandirian keuangan daerah berpengaruh terhadap IPM. Pertumbuhan ekonomi tidak berpengaruh terhadap IPM kabupaten/kota Provinsi Banten. Kesimpulan penelitian ini adalah rasio kemandirian keuangan daerah serta pertumbuhan ekonomi berpengaruh terhadap IPM kabupaten/kota Provinsi Banten tahun 2013 sampai 2017.
\end{abstract}

Kata Kunci : Rasio Kemandirian Keuangan Daerah, Pertumbuhan Ekonomi, Indeks Pembangunan Manusia, Provinsi Banten

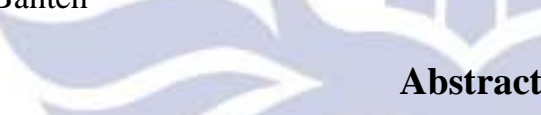

The background of this research is the problem of human development in Banten Province from the educational dimension, namely the problem of inequality and inequality caused by limited government budget in the field of education. This type of research is quantitative research, because the data and research results are in the form of numbers. The purpose of this study is (1) to analyze the effect of the ratio of regional financial independence to HDI. (2) analyze the effect of economic growth on HDI and (3) analyze the effect of the ratio of regional financial independence and joint economic growth on the HDI of regencies / cities in Banten Province in the 2013-2017 period. The population in this study amounted to 40 in 8 districts / cities of Banten Province with a span of 5 years from 2013 to 2017. The sample of this study was a saturated sample using all population members totaling 40 data. Data analysis techniques using panel data regression were processed with Eviews 9.0 application. The results of this study are that there is a simultaneous influence between the independent variable and the dependent variable. While partially, the ratio of regional financial independence affects HDI. Economic growth has no effect on the HDI of regencies / cities in Banten Province. The conclusion of this study is the ratio of regional financial independence and economic growth affect the HDI regency / city of Banten Province in 2013 to 2017.

Keywords : Regional Financial Independence Ratio, Economic Growth, Human Development Index, Banten Province 


\section{PENDAHULUAN}

Aset kekayaan yang dimiliki negara selain aset sumber daya alam adalah sumber daya manusianya. Sudah sepantasnya manusia merupakan tujuan paling penting dalam pembangunan. Salah satunya adalah peningkatan pembangunan manusia di suatu negara. Menurut Badan Pusat Statistik (2015) Indeks Pembangunan Manusia (IPM) adalah proses perluasan pemilihan dalam masyarakat, namun pemilihan tersebut meliputi tiga aspek mendasar meliputi kesehatan, pendidikan serta standar kehidupan yang layak. Peningkatan pembangunan manusia indikatornya ditentukan oleh dimensi kesehatan, ekonomi dan pendidikan. Kesehatan diukur menggunakan Angka Harapan Hidup (AHH). Kemudian dimensi ekonomi disebut sebagai dimensi standar hidup layak dan diukur oleh indikator pengeluaran perkapita disesuaikan.

Selanjutnya, dimensi pendidikan diukur oleh Harapan Lama Sekolah (HLS) dan Rata-rata Lama Sekolah (RLS) sebagai indikatornya. Menurut Badan Pusat Statistik (2019) RLS merupakan rata-rata lamanya penduduk usia 25 tahun keatas untuk menempuh atau menyelesaikan pendidikan formal. Apabila RLS semakin tinggi dapat disimpulkan bahwa kualitas pendidikan penduduk di suatu negara semakin baik. Penelitian ini IPM diukur dengan menggunakan RLS. Adapun RLS berguna untuk mengetahui seberapa baik kualitas penduduk di suatu negara berdasarkan pada lamanya pendidikan formal yang telah diselesaikan. Semakin lama pendidikan yang ditempuh oleh individu, maka ilmu pengetahuan, keterampilan serta keahliannya juga semakin meningkat, sehingga produktivitasnya juga meningkat.

Masalah pembangunan manusia, terutama dimensi pendidikan di Indonesia yang sesuai dengan indikator pembangunan manusia adalah rendahnya RLS penduduk di Indonesia. Menurut Badan Pusat Statistik (2019) RLS penduduk usia 25 tahun keatas di Indonesia periode 2013 sampai 2017, rata-rata penduduk Indonesia bersekolah sampai kelas VIII SMP (belum tamat) atau kurang dari 12 tahun bahkan dapat dikatakan penduduk Indonesia paling banyak menamatkan pendidikan pada jenjang pendidikan menengah, sehingga belum mencapai target minimal wajib belajar 12 tahun.

Permasalahan pembangunan manusia tak hanya terjadi secara nasional saja, tetapi permasalahan tersebut juga terjadi di daerah, khususnya permasalahan pembangunan manusia dimensi pendidikan yang salah satunya adalah RLS penduduknya. Menurut Badan Pusat Statistik (2017) RLS Provinsi Banten tahun 2017 sebesar 8,53 tahun dan berada di peringkat ke-13 dari 34 provinsi di Indonesia. Hal tersebut menandakan bahwa penduduk di Provinsi Banten cenderung menamatkan pendidikannya dari tingkat sekolah dasar sampai kelas VIII atau pendidikan menengah pertama. Tidak hanya itu saja, permasalahan pendidikan di Provinsi Banten salah satunya adalah kesenjangan dan ketidakmerataan pendidikan yang disebabkan oleh keterbatasan anggaran yang diterima pemerintah maupun sekolah guna peningkatan pelayanan pendidikan masyarakat.
Adapun solusi yang harus dilakukan untuk menangani masalah IPM khususnya dimensi pendidikan adalah dengan memberikan dana Bantuan Operasional Sekolah (BOS), dana Beasiswa Siswa Miskin (BSM), serta Kartu Indonesia Pintar (KIP) kepada sekolah-sekolah maupun masyarakat yang berhak menerimanya. Bantuan tersebut diharapkan dapat meringankan beban yang ditanggung masyarakat untuk meneruskan jenjang pendidikan yang lebih tinggi. Selain solusi tersebut, solusi lainnya adalah dengan membangun dan memperbaiki akses serta infrastruktur penunjang pendidikan seperti pembangunan sekolah baru, penambahan kelas baru dan pembangunan serta perbaikan akses jalan dan jembatan yang menuju sekolah-sekolah.

Apabila kualitas pendidikan masyarakat di suatu provinsi tinggi, hal tersebut akan berdampak pada peningkatan IPM terutama rata-rata lama sekolah juga semakin meningkat. Sehingga hal tersebut menyebabkan perolehan PAD suatu provinsi semakin tinggi, karena PAD berdampak terhadap peningkatan kemandirian keuangan daerah. Apabila kemandirian keuangan suatu daerah tinggi, berarti daerah tersebut mampu membiayai dan mensubsidi fasilitas serta kepentingan pendidikan secara mandiri guna meningkatkan rata-rata lama sekolah penduduknya. Menurut Soejoto et al., (2019) modal manusia atau human capital adalah modal non fisik yang ada di dalam diri manusia, dimana modal ini mempengaruhi kualitas sumber daya manusia dan produktivitasnya. Modal manusia terdiri dari keahlian, kesehatan dan tingkat pendidikan yang secara langsung dapat mempengaruhi kualitas individu. Menurut Todaro (2000) berpendapat bahwa bidang pendidikan dan kesehatan dapat digunakan untuk mengukur human capital.

Menurut Halim (2001) Rasio Kemandirian Keuangan Daerah (RKKD) adalah kesanggupan pembiayaan oleh pemerintah daerah untuk kegiatan pemerintah yang meliputi pembangunan, ekonomi serta pelayanan terhadap kepentingan masyarakat yang bersedia membayarkan pajak serta retribusi daerah dan digunakan untuk menambah sumber PAD. Indikator penelitian ini sama dengan variabel RKKD yang diperoleh dari hasil perhitungan antara PAD dan Dana Perimbangan.

Menurut Nugraha \& Amelia (2017) pengaruh rasio kemandirian keuangan daerah terhadap kesejahteraan masyarakat (berdasarkan IPM) berpengaruh positif, artinya peningkatan kemandirian keuangan daerah dilihat dari perolehan PAD terhadap dana perimbangan serta meningkatkan IPM. Adapun peningkatan PAD dapat meningkatkan anggaran belanja daerah untuk pembiayaan sektor menguntungkan dan memiliki nilai manfaat jangka panjang. Salah satunya adalah pengalokasian dana untuk pembangunan manusia. Dimana alokasi tersebut salah satunya digunakan untuk dimensi pendidikan seperti beasiswa bagi siswa yang kurang mampu, perbaikan fasilitas penunjang pendidikan dan dana bantuan pendidikan lainnya.

Menurut Kusumawati \& Wiksuana (2018) semua aktivitas produksi barang serta jasa yang dapat meningkatkan perekonomian negara pada periode tertentu disebut sebagai pertumbuhan ekonomi. Menurut 
Kementrian Keuangan Indonesia (2017) menyatakan di Indonesia pertumbuhan ekonomi sebesar 5,07\% tahun 2017. Meningkatnya pertumbuhan ekonomi nasional tidak lepas dari pertumbuhan ekonomi di daerah-daerah. Khususnya Provinsi Banten yang pertumbuhan ekonominya ditopang oleh sektor pariwisata sebagai sektor yang menjadi tumpuan pendapatan dan pertumbuhan ekonomi daerah. Adapun indikator pertumbuhan ekonomi adalah Laju Pertumbuhan Ekonomi (LPE) diperoleh melalui perhitungan Produk Domestik Regional Bruto (PDRB) Atas Dasar Harg Konstan (ADHK) 2010 sebagai tahun dasarnya. Peningkatan pertumbuhan ekonomi, terutama di Provinsi Banten berasal dari upaya pemerintah provinsi untuk memaksimalkan pendapatan sektor-sektor yang ada dan paling menguntungkan, demi kesejahteraan masyarakat.

Adapun pengaruh pertumbuhan ekonomi terhadap IPM menurut Rakhmawati et al., (2017) yang berpendapat bahwa secara signifikan pertumbuhan ekonomi memiliki pengaruh kepada IPM. Ketika pertumbuhan ekonomi suatu wilayah naik, maka hal tersebut juga akan menaikkan IPM. Dimana peningkatan IPM tersebut juga bisa meningkatkan RLS penduduknya. Tujuan penelitian ini untuk (1) menganalisis pengaruh RKKD terhadap IPM. (2) menganalisis pengaruh pertumbuhan ekonomi terhadap IPM dan (3) menganalisis pengaruh RKKD serta pertumbuhan ekonomi secara bersama-sama terhadap IPM kabupaten/kota Provinsi Banten tahun 2013-2017.

\section{METODE}

Penelitian ini menggunakan penelitian kuantitatif. Dimana data dan hasil penelitian ini berbentuk angka. Jenis data pada penelitian ini adalah sekunder dengan bentuk panel yang diunduh pada website BPS pusat dan BPS Provinsi Banten yang terdiri dari 8 kabupaten/kota Provinsi Banten pada periode 2013-2017.

Populasi pada penelitian berjumlah 40 data, meliputi 8 kabupaten/kota di Provinsi Banten dan rentang waktunya 5 tahun. Dimana populasi tersebut terdiri dari data RKKD, pertumbuhan ekonomi serta IPM kabupaten/kota Provinsi Banten. Sampel penelitian ini adalah sampel jenuh yang meliputi seluruh anggota populasi yang terdiri dari data rasio kemandirian keuangan daerah (diperoleh dari hasil pembagian PAD dengan dana perimbangan), pertumbuhan ekonomi (diukur dengan PDRB ADHK 2010) dan IPM (diukur dengan RLS). Teknik analisis datanya adalah regresi linier berganda yang diolah menggunakan aplikasi pengolah data Eviews 9. Adapun data deret waktunya dari 2013 sampai 2017 selama 5 tahun. Kemudian data deret sektornya meliputi 8 kabupaten/kota Provinsi Banten.

Ada tiga model regresi data panel yang digunakan, yaitu Commond Effect Model (CEM), Fixed Effect Model (FEM) dan Random Effect Model (REM). Kemudian pemilihan model regresi data panelnya dengan Uji Chow dan Hausman. Sehingga, model regresi yang terpilih setelah melakukan kedua uji tersebut adalah FEM.
Setelah regresi data panel ditentukan modelnya, selajutnya melakukan uji hipotesis terdiri dari : (1) Uji Koefisiensi Determinasi (R2), (2) Uji F atau Simultan dan (3) Uji T atau Parsial.

\section{HASIL PENELITIAN DAN PEMBAHASAN \\ Hasil Penelitian}

Untuk pemilihan model antara FEM dan CEM menggunakan Uji Chow yang disajikan di Tabel 1.

Tabel 1. Hasil Uji Chow

\begin{tabular}{|c|c|c|c|c|}
\hline Effect Test & Statistic & d.f. & Prob. & Sign 5\% \\
\hline Cross-section F & 462.720196 & $(7,30)$ & 0.0000 & $<$ \\
\hline Chi-square & 187.642187 & 7 & 0.0000 & $<$ \\
\hline
\end{tabular}

Pada Tabel 1. uji chow diketahui nilai probabilitas Fhitung (Cross-section F) sebesar 462,72 dengan nilai peluang (Prob) sebesar 0,00 (kurang dari 0,05), sehingga menerima H1 dan menolak H0. Dengan demikian, model yang paling tepat digunakan adalah FEM untuk sementara.

Adapun pemilihan model antara FEM dan REM menggunakan Uji Hausman, hasilnya di Tabel 2.

Tabel 2. Hasil Uji Hausman

\begin{tabular}{|c|c|c|c|c|}
\hline $\begin{array}{c}\text { Test } \\
\text { Summary }\end{array}$ & $\begin{array}{c}\text { Chi-Sq. } \\
\text { Statistic }\end{array}$ & $\begin{array}{c}\text { Chi-Sq. } \\
\text { d.f. }\end{array}$ & Prob. & $\begin{array}{c}\text { Sign } \\
\mathbf{5 \%}\end{array}$ \\
\hline $\begin{array}{c}\text { Cross-section } \\
\text { random }\end{array}$ & 10.297611 & 2 & 0.0058 & $<$ \\
\hline
\end{tabular}

Statistic) yaitu 10.29 yang nilai (Prob) sebesar 0.0058 (kurang dari 0,05), maka kesimpulannya adalah menolak H0, menerima H1. Maka FEM adalah model yang tepat digunakan. Sehingga tidak perlu dilakukan uji LM.

Hasil output model terpilih yaitu FEM dan selajutnya melakukan uji hipotesis.

Tabel 3. Hasil output FEM

Dependent
Variable:
IPM
Method: Panel Least Squares
Date: $12 / 14 / 19$ Time: 07:47
Sample: 2013 2017
Periods included: 5
Cross-sections included: 8
Total panel (balanced) observations: 40

\begin{tabular}{|c|c|c|c|c|}
\hline Variable & Coefficient & Std. Error & t-Statistic & Prob. \\
\hline $\mathrm{C}$ & 8.432627 & 0.281986 & 29.90438 & 0.0000 \\
\hline RKKD & 0.277188 & 0.101626 & 2.727521 & 0.0106 \\
\hline \multirow{2}{*}{\multicolumn{5}{|c|}{$\begin{array}{l}\text { PERTUMB } \\
\text { UHAN EK }\end{array}$}} \\
\hline & & & & \\
\hline \multirow[t]{2}{*}{ ONOMI } & -2.863506 & 4.110740 & -0.696591 & 0.4914 \\
\hline & \multicolumn{4}{|c|}{ Effects Specification } \\
\hline \multicolumn{5}{|c|}{ Cross-section fixed (dummy variables) } \\
\hline $\begin{array}{l}\text { R-squared } \\
\text { Adjusted }\end{array}$ & 0.996838 & \multicolumn{2}{|c|}{ Mean dependent var } & 8.452250 \\
\hline R-squared & 0.995889 & \multicolumn{2}{|c|}{ S.D. dependent var } & 1.847862 \\
\hline
\end{tabular}


S.E. of

\begin{tabular}{llll}
$\begin{array}{l}\text { regression } \\
\text { Sum }\end{array}$ & 0.118476 & Akaike info criterion & -1.215898 \\
squared & & & \\
resid & 0.421095 & Schwarz criterion & -0.793679 \\
$\begin{array}{l}\text { Log } \\
\text { likelihood }\end{array}$ & 34.31797 & Hannan-Quinn criter. & -1.063237 \\
$\begin{array}{l}\text { F-statistic } \\
\text { Prob(F- }\end{array}$ & 1050.815 & Durbin-Watson stat & 1.033106 \\
statistic) & 0.000000 & & \\
\hline
\end{tabular}

Menurut Hadi (2019) untuk mengetahui variasi variabel dependen (Y) yang dapat dijelaskan variabel independen (X) dengan melakukan uji R2. Apabila koefisien determinasinya $=0(\mathrm{R} 2=0)$, artinya keseluruhan variasi variabel dependen tidak bisa dijelaskan oleh variabel independen,. Namun, apabila koefisien determinasinya $=1(\mathrm{R} 2=1)$, maka seluruh variasi variabel dependen dapat dijelaskan oleh variabel independen. Jika perubahan variabel dependen mampu dijelaskan secara keseluruhan oleh variabel independen maka R2 semakin mendekati 1. Sebaliknya, jika R2 menjauhi 1, maka artinya variabel dependen tidak mampu dijelaskan variabel independen. Adapun uji R2 dapat dilihat hasilnya pada $R$-square di Tabel 4.

Tabel 4. Hasil Uji Koefisien Determinasi (R2)

\begin{tabular}{|c|c|}
\hline Cross-section fixed & Skor \\
\hline R-squared & 0.996838 \\
\hline Adjusted R-squared & 0.995889 \\
\hline S.E. of regression & 0.118476 \\
\hline Sum squared resid & 0.421095 \\
\hline Log likelihood & 34.31797 \\
\hline F-statistic & 1050.815 \\
\hline Prob(F-statistic) & 0.000000 \\
\hline
\end{tabular}

Menurut Ghozali (Suryandari, 2017) uji F (simultan) adalah mengetahui ada atau tidak pengaruh semua variabel independen terhadap variabel dependen secara bersama-sama atau simultan dengan nilai signifikan 0,05 (5\%). Adapun uji F dilihat melalui $\operatorname{Prob}(F$-statistic $)$ di Tabel 5.

Tabel 5. Hasil Uji F (Simultan)

\begin{tabular}{|c|c|c|}
\hline Cross-section fixed & Skor & Sign 5\% \\
\hline Prob(F-statistic) & 0.000000 & $<$ \\
\hline
\end{tabular}

Menurut Hadi (2019) uji T (parsial) adalah untuk mengetahui kemampuan variabel independen dapat menjelaskan variabel dependen secara sendiri-sendiri. Adapun variabel independen dianggap memiliki nilai konstan apabila tingkat signifikansinya sebesar 0,05 (5\%). Uji T hasilnya bisa dilihat di Tabel 6.

Tabel 6. Hasil Uji T (Parsial)

\begin{tabular}{|c|c|c|c|}
\hline Variabel & Koefisien & Prob & Sign 5\% \\
\hline $\begin{array}{c}\text { Rasio Kemandirian } \\
\text { Keuangan Daerah } \\
\text { (RKKD) (X1) }\end{array}$ & 0.277188 & 0.0106 & $<$ \\
\hline $\begin{array}{c}\text { Pertumbuhan } \\
\text { Ekonomi (X2) }\end{array}$ & -2.863506 & 0.4914 & $>$ \\
\hline
\end{tabular}

\section{Pembahasan}

Pengaruh Rasio Kemandirian Keuangan Daerah terhadap Indeks Pembangunan Manusia Kabupaten Kota di Provinsi Banten

Berdasarkan dari hasil uji T maka ditarik kesimpulan variabel RKKD diukur dengan indikator RKKD yang probabilitasnya (Prob) sebesar $(0.0106<0,05)$ dengan signifikansi 5\%. Sehingga disimpulkan variabel RKKD berpengaruh positif dengan variabel IPM kabupaten kota Provinsi Banten. Karena semakin tinggi RKKD, maka potensi peningkatan IPM terutama dimensi pendidikan akan semakin meningkat.

Adapun penelitian tersebut sesuai dengan penelitian Iskandar \& Subekan (2014) yaitu RKKD berhubungan positif signifikan terhadap IPM. Dimana, semakin tinggi RKKD, maka hal tersebut akan mendorong peningkatan IPM terutama dimensi pendidikan sejalan dengan naiknya RLS penduduknya.

Penelitian ini sejalan dengan penelitian Nugraha \& Amelia (2017) RKKD berpengaruh positif terhadap kesejahteraan masyarakat. Dimana kesejahteraan masyarakat tersebut salah satunya adalah pendidikan dengan gambaran RLS yang merupakan capaian IPM.

Namun penelitian ini bertolak belakang dengan penelitian Handayani \& Sriyunianti (2016) RKKD berpengaruh negatif dengan IPM. Kemudian bertolak belakang dengan penelitian Anggaraini \& Sutaryo (2015) yaitu RKKD berpengaruh negatif signifikan terhadap IPM.

Pengaruh Pertumbuhan Ekonomi terhadap Indeks Pembangunan Manusia di Kabupaten Kota Provinsi Banten

Berdasarkan uji $\mathrm{T}$, variabel pertumbuhan ekonomi diukur menggunakan indikator LPE (Laju Pertumbuhan Ekonomi) yang merupakan hasil perhitungan Produk Domestik Bruto (PDRB) dengan hasil nilai probabilitas (Prob) $(0.4914>0,05)$ dengan taraf signifikansi 5\%. Jadi dapat disimpulkan bahwa pertumbuhan ekonomi tidak berpengaruh terhadap IPM kabupaten/kota Provinsi Banten. Hal tersebut menandakan bahwa peningkatan maupun penurunan IPM tidak dipengaruhi oleh pertumbuhan ekonomi.

Namun, hasil tersebut bertolak belakang dengan teori modal manusia menurut Tobing (Wijaya, 2017) dimana teori tersebut dipelopori oleh Gery Becker yang menyatakan bahwa pertumbuhan ekonomi suatu wilayah dipengaruhi oleh kualitas SDM di wilayah tersebut, salah satunya adalah dari kualitas pendidikannya.

Adapun penelitian ini hasilnya tidak sesuai dengan penelitian Retnasari (2015) berpendapat, pertumbuhan ekonomi berpengaruh terhadap tingkat IPM. Hal tersebut menandakan bahwa, IPM meningkat pertumbuhan ekonomi juga meningkat. Penelitian ini tidak sependapat dengan penelitian Rakhmawati et al., (2017) yaitu adanya pengaruh signifikan pertumbuhan ekonomi terhadap IPM, karena apabila pertumbuhan ekonomi suatu wilayah naik, hal tersebut juga menaikkan IPM, dimana peningkatan IPM juga akan meningkatkan RLS penduduknya. 
Penelitian ini juga tidak sesuai hasil penelitian Lugastoro (2013) yaitu hubungan timbal balik antara pertumbuhan ekonomi dan pembangunan manusia, meskipun pengaruhnya tidak secara langsung namun dapat diperkuat oleh kebijakan yang dikeluarkan pemerintah.

Pengaruh Rasio Kemandirian Keuangan Daerah dan Pertumbuhan Ekonomi terhadap Indeks Pembangunan Manusia Kabupaten Kota di Provinsi Banten

Berdasarkan uji F maka variabel independen memiliki nilai signifikan (F-statistic) sebesar 1050,815. Dimana Prob (F-statistic) adalah 0.000000 lebih kecil dari 0,05. Kesimpulannya adalah secara bersamaan rasio kemandirian keuangan daerah serta pertumbuhan ekonomi berpengaruh dengan IPM. Karena semakin meningkatnya RKKD serta pertumbuhan ekonomi maka peningkatan IPM juga akan semakin besar terutama pada dimensi pendidikan.

Sehingga uji $\mathrm{F}$ penelitian ini kesimpulannya adalah variabel RKKD dengan pertumbuhan ekonomi menjadi salah satu penyebab dari peningkatan dan penurunan IPM kabupaten kota Provinsi Banten.

Sejalan dengan penelitian Dewi \& Sutrisna (2014) dimana kemandirian keuangan daerah serta pertumbuhan ekonomi berdampak signifikan terhadap IPM. Dimana jika kemandirian keuangan daerah dan pertumbuhan ekonomi meningkat, IPM akan meningkat dan sebaliknya.

Adapun menurut Todaro dan Smith (Supartoyo et al., 2013) dalam aliran Neo Klasik pertumbuhan ekonomi dipengaruhi oleh tiga faktor, meliputi kualitas dan kuantitas tenaga kerja yang meningkat, kemajuan teknologi serta penambahan modal. Modal tidak berasal dari SDA saja namun juga dari SDM. Agar sumber daya manusia meningkat (IPM) salah satunya caranya adalah kualitas pendidikan manusianya lebih ditingkatkan.

\section{PENUTUP}

\section{Simpulan}

Setelah melakukan analisis serta pembahasan hasil penelitian yang dijelaskan sebelumnya, maka simpulannya adalah : (1) RKKD berpengaruh dengan IPM kabupaten/kota Provinsi Banten 2013 sampai 2017. (2) Pertumbuhan ekonomi tidak berpengaruh kepada IPM kabupaten/kota Provinsi Banten 2013 sampai 2017. (3) RKKD serta pertumbuhan ekonomi berpengaruh signifikan dengan IPM kabupaten/kota di Provinsi Banten tahun 2013 sampai 2017.

\section{Saran}

Adapun saran penelitian ini setelah melihat simpulannya adalah : (1) Komponen rasio kemandirian keuangan daerah terutama PAD harus lebih ditingkatkan perolehannya. Serta lebih dioptimalkan penggunaannya, karena dapat memberikan keuntungan bagi perolehan PAD yang bermanfaat untuk meningkatkan pembangunan manusia khususnya dimensi pendidikan. (2) Pertumbuhan ekonomi harus lebih ditingkatkan lagi, dan peningkatan pertumbuhan ekonomi berasal dari peningkatan faktor- faktor produksi. Peningkatan faktor produksi tidak lepas dari kualitas SDM dan pembangunan manusia yang disebabkan oleh jenjang pendidikan yang telah ditempuh oleh penduduk kabupaten kota di Banten. (3) Variabel pertumbuhan ekonomi diukur berdasarkan laju pertumbuhan ekonomi yang merupakan hasil perhitungan dari PDRB ADHK tidak berpengaruh terhadap IPM diukur menggunakan RLS. Sehingga saran yang diberikan untuk penelitian selanjutnya adalah menggunakan indikator lain untuk mengukur pertumbuhan ekonomi.

\section{DAFTAR PUSTAKA}

Anggraini, T., \& Sutaryo. (2015). Pengaruh Rasio Keuangan Pemerintah Daerah terhadap Indeks Pembangunan Manusia Pemerintah Provinsi di Indonesia. Jurnal Ilmiah Tidak Diterbitkan .

Badan Pusat Statistik. (2016). Indeks Pembangunan Manusia 2015. Jakarta: Badan Pusat Statistik.

Badan Pusat Statistik. (2018). Indeks Pembangunan Manusia 2017. Jakarta: Badan Pusat Statistik.

Badan Pusat Statistik. (2019). Rata-rata Lama Sekolah Kabupaten Kota di Banten 2010-2018 (Metode Baru). Retrieved December 28, 2019, from Direktorat Analisis dan Pengembangan Statistik website:

https://ipm.bps.go.id/data/provinsi/metode/baru/36 00

Badan Pusat Statistik. (2019). Sirusa : Sistem Informasi Rujukan Akademik. Retrieved January 25, 2020, from Subdit Rujukan Statistik website: https://www.google.com/url?q=https://sirusa.bps.go .id/sirusa/index.php/indikator/572\&usg=AOvVaw0 UdL6dP3MvlnLo0_6CTB2N

Dewi, P. A. K., \& Sutrisna, I. K. (2014). Pengaruh Kemandirian Keuangan Daerah dan Pertumbuhan Ekonomi terhadap Indeks Pembangunan Manusia di Provins Bali. E-Jurnal Ekonomi Pembangunan Universitas Udayana, 4(1), 32-40.

Hadi, L. O. M. A. F. P. (2019). Pengaruh PDRB, Tingkat Pendidikan, Tingkat Kesehatan, dan Pengeluaran Pemerintah terhadap Tingkat Kemiskinan di Provinsi Jawa Timur (Periode Tahun 2010-2017). Universitas Islam Indonesia.

Halim, A. (2001). Akuntansi Sektor Publik-Akuntansi Keuangan Daerah. Jakarta: Salemba Empat.

Handayani, D., \& Sriyunianti, F. (2016). Analisa Kinerja Keuangan terhadap Indeks Pembangunan Manusia Kabupaten Kota di Sumatera Bagian Tengah. National Conference of Applied Sciences, Engineering, Business and Information Technology. Padang: Politeknik Negeri Padang. 
Iskandar, A., \& Subekan, A. (2014). Kinerja Keuangan Daerah dan Kesejahteraan Rakyat di Era Desentralisasi Fiskal (Studi Empiris pada Kabupaten/Kota provinsi Sulawesi Selatan TA 2008-2012). Jurnal Info Artha Sekolah Tinggi Akuntansi Negara (STAN), 1(12), 79-101. Retrieved from https://mpra.ub.unimuenchen.de/77677/

Kementrian Keuangan Republik Indonesia. (2017). Pertumbuhan Perekonomian Indonesia Triwulan I2017 Meningkat. Retrieved August 9, 2019, from Manajemen Situs Kemenkeu website: https://www.kemenkeu.go.id/publikasi/berita/pertu mbuhan-perekonomian-indonesia-triwulan-i-2017meningkat/

Kusumawati, L., \& Wiksuana, I. G. B. (2018). Pengaruh Pendapatan Daerah terhadap Pertumbuhan Ekonomi di Wilayah Sarbagita Provinsi Bali. EJurnal Manajemen Universitas Udayana, 7(5), 2592-2620.

https://doi.org/https://doi.org/10.24843/EJMUNUD .2018.v7.i05.p12

Lugastoro, D. P. (2013). Analisis Pengaruh PAD dan Dana Perimbangan terhadap Indeks Pembangunan Manusia Kabupaten/Kota di Jawa Timur. Jurnal Ilmiah Tidak Diterbitkan, 1-19.

Nugraha, \& Amelia, T. (2017). Pengaruh Dana Perimbangan dan Kemandirian Keuangan Daerah tehadap Kesejahteraan Masyarakat pada Kabupaten dan Kota di Jawa Barat Tahun 2011-2014. Jurnal Wacana Kerja Universitas Pendidikan Indonesia, 20(1), 51-72.

Rahmawati, K. D. (2017). Analisis Pengaruh Jumlah Penduduk, Tingkat Pendidikan dan Tingkat Pengangguran terhadap Kemiskinan di DIY Periode 2006-2013. Universitas Islam Negeri Sunan Kalijaga.

Rakhmawati, Z., Nazar, M. R., \& Zultilisna, D. (2017). Pengaruh Pertumbuhan Ekonomi, Pendapatan Asli Daerah dan Belanja Daerah terhadap Indeks Pembangunan Manusia (Studi Pada Kota dan Kabupaten di Provinsi Jawa Barat Periode 20102014). E-Proceeding of Management, 4(2), 17091714. Bandung: Universitas Telkom.

Retnasari, E. D. (2015). Pengaruh Nilai Tukar Petani dan Pertumbuhan Ekonomi terhadap Indeks Pembangunan Manusia Di Provinsi Jawa Timur. Jurnal Pendidikan Ekonomi (JUPE) Universitas Negeri Surabaya, 3(3), 1-6.

Soejoto, Ady Rafsanjani, Mohamad Arief Pamungkas, Heni Purwa Kamalia, P. U. (2019). Ekonomi Pendidikan. Surabaya: UNESA University Press.
Supartoyo, Y. H., Tatuh, J., \& Sendow, R. H. E. (2013, July). The Economic Growth and The Regional Characteristic: The Case of Indonesia. Buletin Ekonomi Moneter Dan Perbankan, 3-19.

Suryandari, A. N. (2017). Pengaruh Pertumbuhan Ekonomi, Pendidikan, dan Kesehatan terhadap Tingkat Kemiskinan di Provinsi Daerah Istimewa Yogyakarta Tahun 2004-2014. Universitas Negeri Yogyakarta.

Todaro, M. P. (2000). Economic Development (Edisi 7). New York: University Addison Wesley.

Wijaya, D. (2017). Ekonomi Pendidikan (Edisi 1). Yogyakarta: Media Pengetahuan. 